\title{
OXFORD

Paradise, pleasure and desire: Edenic delight in some latemedieval dramatic fragments

\begin{tabular}{|r|l|}
\hline Journal: & Literature and Theology \\
\hline Manuscript ID & Draft \\
\hline Manuscript Type: & Article \\
\hline Keyword: & medieval literature, pleasure, paradise \\
\hline & \\
\hline
\end{tabular}

SCHOLARONE ${ }^{\text {M }}$

Manuscripts 


\title{
Paradise, pleasure and desire: Edenic delight in some late-medieval dramatic fragments
}

\author{
DUBIUS Lorde, syr, what thynge is paradyse, \\ and what place may it be? \\ LUCIDUS Syr, a place of al delyte it is. \\ Herkene and y wyl tellen the. ${ }^{1}$
}

In the beginning, God created heaven and earth, as all medieval Christians knew; they knew, too, that the first man and woman were placed by their maker in Paradise, an idyllic Garden created for them as their home, but from which they and all future generations were excluded following the Fall. ${ }^{2}$ This exclusion aroused a curiosity to know more about the earthly Paradise, a curiosity satisfied by a series of theological speculations and literary conventions about its appearance and qualities which were developed from the earliest Christian centuries and throughout the Middle Ages.

Existing scholarship on the subject of medieval ideas of Paradise is extensive, and there is space here to consider only a few recent examples. Jean Delumeau's engaging study takes a relatively 'popular' approach, providing a broad historicized account of the concept of Paradise and of its interpretation. ${ }^{3}$ By contrast, Guy Geltner provides an erudite and very focused discussion of the idea of the Garden of Eden in Franciscan discourse, where it is employed in support of poverty and the apostolic life. ${ }^{4}$ Alessandro Scafi's 2006 cartographical study is focused primarily on the location of the earthly Paradise as it appears in medieval maps, although he provides some useful insights into the topographical 
terminology employed to describe it. ${ }^{5}$ In his unpublished PhD thesis, Robert Brandon II situates the concept of Paradise in relation to contemporary cultural values and social practices, examined through the lens of three Middle English literary texts. ${ }^{6}$ Most recently, Winston Black's thought-provoking Traditio article explores William of Auvergne's rejection of the earthly delights of Paradise in the context of his wider rejection of Islam, explaining William's 'delight-less theology' as a response to his misreading of the Muslim physical paradise. ${ }^{7}$ Black's focus is very much upon William's reception and legacy among an academic, theologically trained elite, and the physical delights that WIlliam scorns are grossly appetitive. My concerns in this essay are rather different; I am interested in exploring the ways in which the ideas of pleasure and delight, with a specific emphasis on physical, sensory and affective experiences, are, in the later Middle Ages, increasingly brought to the fore in descriptions of Paradise; and how this trend is noticeably manifested in three late-medieval dramatic texts. I first discuss some early descriptions of Paradise, and go on to explore the concepts of pleasure and delight as developed in the work of St Augustine and St Thomas Aquinas. Finally I turn to the dramatic texts themselves, considering how they employ the idea of Paradise to further their didactic purposes.

\title{
Early descriptions of Paradise
}

The biblical description of Eden is simultaneously evocative and strangely elusive:

\begin{abstract}
And the Lord God had planted a paradise of pleasure from the beginning: wherein he placed man whom he had formed. And the Lord God brought forth of the ground all manner of trees, fair to behold, and pleasant to eat of: the tree of life also in the midst of paradise: and the tree of knowledge of good and evil. And a river went out
\end{abstract}


of the place of pleasure to water paradise, which from thence is divided into four heads. The name of the one is Phison: that is it which compasseth all the land of Hevilath, where gold groweth. And the gold of that land is very good: there is found bdellium, and the onyx stone. And the name of the second river is Gehon: the same is it that compasseth all the land of Ethiopia. And the name of the third river is Tigris: the same passeth along by the Assyrians. And the fourth river is Euphrates. And the Lord God took man, and put him into the paradise of pleasure, to dress it, and to keep it. ${ }^{8}$

It is easy to be stirred by the idea of a 'paradise of pleasure' (paradisum voluptatis), but more difficult to crystallize the concept; the various trees are, we are told, 'fair to behold, and pleasant to eat of', but the lack of detailed physical description leaves much to the imagination. What description there is focuses on the four rivers which flow out of Paradise, rather than on the interior scene, suggesting perhaps the ineffable nature of the garden itself, and seeking to draw our gaze away from it. Nevertheless, as Delumeau points out, the biblical account tells us enough to reveal its indebtedness to descriptions of other sacred gardens in ancient Eastern religions, while early Christian commentators such as St Justin Martyr, Tertullian and Basil the Great synthesized the scriptural depiction with earlier Greco-Roman traditions of the Golden Age and the Elysian Fields. ${ }^{9}$ This synthesizing work raises the question of whether the biblical Paradise was to be interpreted literally or allegorically, and Augustine, in his Literal Meaning of Genesis, acknowledges three possible ways of reading the text: literally; spiritually; or as a combination of the two. ${ }^{10}$ Having previously drifted in the direction of a purely symbolic interpretation in On Genesis: $A$ Refutation of the Manichees, Augustine here declares his support for the third option, in 
which the literal meaning is to be adhered to as far as possible, with allegorical readings added as and when appropriate. ${ }^{11}$ Thus he asserts that Paradise is a real place, 'shady with groves of fruit trees and extensive too and rendered fertile by a huge spring' (VIII,1,4), and the trees and rivers therein are also to be understood literally, although without denying their capacity to stand figuratively as well (VIII,4,8-7,14). 'All these things', he explains, 'stood for something other than what they were, but at the same time they were themselves bodily realities.' The tree of life, for example, should be understood as a bodily tree and simultaneously as a sacramental sign of Christ as Wisdom, the source of eternal life $(\mathrm{VIII}, 4,8) .{ }^{12}$ Such a dual concept of the earthly Paradise, at once material and spiritually significant, remained highly influential throughout the later Middle Ages, being taken up by Isidore of Seville, Bede and Peter Lombard, among others. ${ }^{13}$

Alongside these theologically sophisticated texts we see the growth of a parallel and more popular tradition, which sought to elucidate the concept of Paradise in terms which were less speculative, and which focused much more on providing both a physical description and an enumeration of its practical human benefits. For example, in the Latin Elucidarium, a quasi-catechetical text in dialogue form written in around 1090 by Ps.-Honorius, the questioning disciple asks his master what and where Paradise is; the master's response is clearly indebted to scripture, but offers some additional information:

Locus amoenissimus in Oriente, in quo arbores diversi generis contra varios defectus erant consitae Verbi gratia, ut, si homo congruo tempore de uno comederet, nunquam amplius esuriret, congruo tempore de alio, et nunquam sitiret, de alio 
vero, et nunquam lassaretur; ad ultimum, ligno vitae uteretur et amplius non senesceret, non infirmaretur, nunquam moreretur. ${ }^{14}$

[The most beautiful place in the east, in which were planted trees of diverse kinds against various defects by grace of the Word, so that, if a man ate of one at a fitting time, he would hunger no more; at a fitting time, of another, and he would thirst no more; of another, and he would be weary no more; at last, enjoy the tree of life and no more grow old, nor sicken, nor die.]

The biblical paradise of pleasure is transformed in the Elucidarium into a locus amoenissimus, a very beautiful place, while the description of the trees, 'pleasant to eat of', is elaborated by a detailed explanation of their beneficial effects. The various trees, described without comment in the biblical account, are here subject to an exegetical approach which endows them with specific virtues which protect against the human ills of hunger, thirst and weariness. The sacramental nature of the tree of life, elaborated by Augustine, is eliminated in favour of a more prosaic account of its therapeutic properties, warding off age, sickness and even death. Such an emphasis on the practical benefits of Paradise, benefits irretrievably lost to mankind after the Fall, surely reflects the increased emphasis on pastoral care brought about by the eleventh-century reform movement; the Elucidarium's propaedeutic nature inevitably results in a focus upon explanations which are framed in human and quotidian terms, and which privilege a literal rather than an allegorical interpretation.

Less than a hundred years later we see this concept of the literal, humanised Paradise extended to the wider created world, and given a rather different emphasis. In the twelfth- 
century Life of Ailred of Rievaulx, the Cistercian Walter Daniel describes the moment when Aelred, then still in secular service, is first told about the community of monks at Rievaulx:

High hills surround the valley, encircling it like a crown. These are clothed by trees of various sorts and maintain in pleasant retreats the privacy of the vale, providing for the monks a kind of second paradise of wooded delight. ${ }^{15}$

The sylvan location of the new Cistercian abbey is a 'second paradise' (alterum paradisum) in which the trees offer private retreats for the enjoyment of the monks. These wooded groves may well be intended to assist in divine meditations, but Daniel does not make this point explicitly, nor does he draw any overt parallel between the retreat into tree-lined privacy in the valley and the much more significant retreat, undertaken by all Cistercians, from the secular to the spiritual world. ${ }^{16}$ Instead this second paradise, like that described by Ps.-Honorius, is an entirely material one, but in a further development it is a paradise in which the pleasure of those within it acquires a new significance:

From the loftiest rocks the waters wind and tumble down to the valley below, and as they make their hasty way through the lesser passages and narrower beds and spread themselves in wider rills, they give out a gentle murmur of soft sound and join together in the sweet notes of a delicious melody. And when the branches of lovely trees rustle and sing together and the leaves flutter gently to the earth, the happy listener is filled increasingly with a glad jubilee of harmonious sound, as so many various things conspire together in such a sweet consent, in music whose 
every diverse note is equal to the rest. His ears drink in the feast prepared for them, and are satisfied. ${ }^{17}$

Daniel's account revels in the sounds of water and trees, combining in their 'glad jubilee of harmonious sound' (iocundum iubilum tam concordantis armonie) to produce a feast for the ears, a sensory cocktail which satisfies the 'happy listener' who drinks it in. By emphasizing the pleasure to be enjoyed in this environment, Daniel's description foregrounds affect; but it is affect constructed with particular literary skill. Of the listening monk he merely tells us that he is 'happy' and his ears are 'satisfied'; the affective power of this passage is created by the agency with which he imbues the natural world. The waters are 'hasty', their murmuring 'gentle' and 'soft', while the 'lovely trees rustle and sing'; together they 'conspire' in 'sweet consent' to prepare a feast for the monk, and, it should be added, for the reader of, or listener to, Daniel's text. This is truly a paradise of delights (delicie paradisum) which brings happiness to the monks therein, and to those who hear or read about it. The Vulgate's 'paradise of pleasure' is, in Daniel's hands, a literal and sensuous one, treated in a manner which initially might seem to owe more to eastern Islamic than to western Christian traditions; ${ }^{18}$ but the careful displacement of affect from the human listener onto nature itself keeps this text delicately poised between spiritual and physical enjoyment, in a manner which becomes an increasingly important strand of medieval piety both within and outside the cloister, in Latin and in the vernacular. ${ }^{19}$

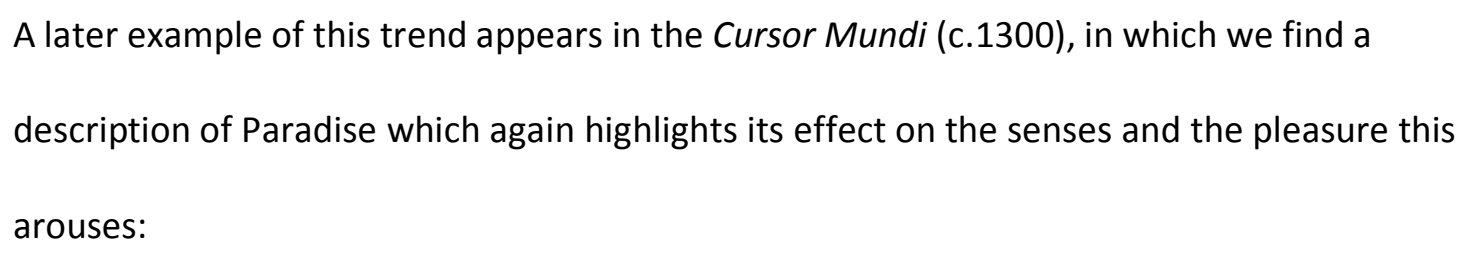


Paradis is a priue stedd, par mani mirthes er e-medd, pe leueleist [loveliest] of all landes;

In erth toward pe est it standes, land o liue, o ro [peace], and rest, Wit blis and beild [protection] broiden best, par neuer neghes nede ne night, Bot euer vmlaid wit lem [brightness] and light.

O selenes [happiness] es it wel sene, pe gresse es euer ilik grene, Wit alkin blis pat par es elles; Flour par es wit suete smelles; $[\ldots]$ It es a yard cald o delites Wit all maner o suet spices. Qua lenges par thar pam noght lang, par sune es soft and suet sang, Sune of sautes [saints] pat par singes. ${ }^{20}$

Paradise here is filled with mirth and woven about with bliss and happiness; the scent of sweet flowers and spices combines with the warmth of the sun and the sounds of singing to produce a garden ('yard') of delights. Once again the senses are quickened and satisfied, and if the Cursor Mundi does not attain the degree of sensuous indulgence offered by 
Daniel's text, it nevertheless suggests a pleasure which is firmly focused on the physical. We might conjecture that the increasing emphasis upon the sensory pleasures of Paradise in the accounts of Walter Daniel and the Cursor Mundi is evidence of a desire among writers and their audiences for particular attention to be given to the notion of sensory enjoyment, and it is to this that I now turn.

\section{Pleasure and delight}

The term delight (delectatio) is employed frequently by Augustine, who understands it to be essential to the functioning of the human will, the motivating force which drives all human behaviour; our actions give us delight, or serve the purpose of bringing us closer to those things in which we take delight. ${ }^{21}$ Delight is thus intimately connected with desire, and hence with seeking its own satisfaction; we desire that which delights us, and the more delight we experience, the more we want. Augustine's philosophy of delight goes much further than this, however; it is not simply an aspect of the human will, but should be regarded as 'first and foremost the affective element of God's love'. ${ }^{22}$ Thus delight is central to human psychology and behaviour because it connects us directly, even quasisacramentally, with God; 'God is all our joy', Augustine asserts, and hence is the source of all mankind's delight. ${ }^{23}$ God is thus the proper object of human delight, and for those who wish to come closer to him, delight necessarily inclines them to God. However, this proper functioning of delight can be and is subject to corruption as a result of original sin; our own sins, therefore, are also accompanied by pleasure. As Augustine points out in the Confessions, when discussing his theft of some pears with a number of juvenile companions, it was not the fruit which they sought: 'our real pleasure consisted in doing something that was forbidden' ${ }^{24}$ Just as with uncorrupted delight, if the pleasure of sinning is great, people 
will incline themselves more and more towards sin in order to increase the pleasure they experience. $^{25}$

Because pleasure accompanies both virtuous and vicious acts, Augustine develops a taxonomy of delight which includes both temporal and spiritual strands. The temporal is divided into two separate elements: the carnal and the worldly. Carnal delight is always evil, since it has as its object the active enjoyment of sin; by contrast worldly delight, consisting of the enjoyment of the perceptions of the senses, is not bad in itself, providing those perceptions are not relished for their own sake, but as a means of moving closer to God. ${ }^{26}$ Finally, delight may be spiritual, having as its object God and those spiritual things emanating from him, and as such it is inherently good. Mark Clavier identifies the crucial distinction between worldly and spiritual delight in Augustine's thought; in the former, 'delight is situated in the subject, who experiences pleasure through his or her various senses [...] Spiritual delight, on the other hand, exists most fully in God: indeed, is God. God does not use delight but is delight. ${ }^{27}$

Like Augustine, Aquinas acknowledges that delight is instinctive; it arises, he says, from objects and activities which are 'naturally congenial' to man. ${ }^{28} \mathrm{He}$ also identifies a taxonomy of pleasures, ranging from the physical and sensory to the rational or intellectual, in which there is an implicit but not unproblematic hierarchy.' 'The higher pleasures', he asserts, 'have as their object things that do not change'; on the other hand, 'the greatest pleasure is that which comes through the senses and requires the actual presence of a sense-object'. ${ }^{29}$ Aquinas, as we might expect, follows Augustine in situating the highest pleasures in the immutable sphere; but these are carefully distinguished from those from which humans 
derive more pleasure, and which arise from their senses. Of course this would not be a problem in the pre-lapsarian Paradise, which, being eternal in God's creation, can be the source of both the greatest and the highest delights simultaneously. However, in the postlapsarian world the objects of the senses decay and die as a matter of necessity, leading to a disjunction between the two; and it is likewise a sign of man's fallen state that he should prefer the lower ranked pleasure over the higher. Having established this hierarchy, Aquinas also identifies the role of 'wondering' (admiratio) in the experience of delight, explaining that wonder is aroused by that which we do not fully understand, and results in pleasure if we are able to arrive at comprehension: 'this is why anything that arouses wonder can give pleasure ${ }^{\prime 30}$ This heuristic account is akin to, though not identical with, Augustine's emphasis on desire, and again underlines the active aspect of delight, a point to which I shall return.

\section{Paradisum voluptatis}

I now turn to consider the concept of the paradise of pleasure in three anonymous dramatic texts or fragments of the late fourteenth and fifteenth centuries: the Cornish play Origo Mundi; the dialogue Lucidus and Dubius, which is loosely based on the Latin Elucidarium; and the 'Speech of Delight' from the so-called Reynes Extracts. ${ }^{31}$ Origo Mundi is the first in the trilogy of plays known as the Ordinalia, and the manuscript contains both detailed stage directions and staging plans suggesting performance in open-air amphitheatres or rounds. ${ }^{32}$ Lucidus and Dubius takes the form of a dramatic dialogue, and while its tone is didactic, its subject matter largely catechetical, and there is little in the way of 'action' as traditionally conceived, the manuscript's mise-en-page is consistent with the usual presentation of dramatic texts, with bracketed rhymes and lines separating each speech, suggesting that it was intended for performance. The 'Speech of Delight' is described in the printed catalogue 
of the Tanner manuscripts as 'A poem on delight', but as Iris Calderhead rightly notes, it is in fact a speech by a character named Delight, and is presumably part of a text for a morality play, a view with which Richard Rastall concurs. ${ }^{33}$ The content and purpose of each of these texts varies considerably, from a fully dramatized account of the creation of the world, to an exposition of Christian faith for the neophyte, to a single disembodied speech. Yet they are united in containing an account, however brief, of a created paradise and of its sensory delights, and the similarity is not merely of content; at the linguistic level, too, there are parallels which suggest that each of these texts is drawing on a shared tradition, shaping the way in which the biblical Paradise, and indeed the wider created world, is perceived and described.

About a third of the way into Lucidus and Dubius, Dubius, the self-confessed sower of doubts and heresies, raises the subject of Paradise and Lucidus is quick to respond:

LUCIDUS It is a place grene and swete, of spysis, trees, and of flouris, with-oute hungere, colde, or hete, with-oute tempest or shouris;

ryveris rennynge, songe ful swete, mirthe, ioy with-oute ende, lyf and helthe shul euer mete, age and seeknes shul thennys wende. 
There is froyt folke with to fede, lusty to mete for all seeknes;

pere is no sorowe, doute, ne drede; euerlastynge lyf and all goodnes. (202-17)

The Latin source of this text, as I have described above, addresses this question by explaining the advantages of remaining in Paradise and enjoying the fruits therein, but the emphasis in Lucidus and Dubius is considerably more sensuous. The locus amoenissimus with its practical human benefits is elaborated as a garden of sensory delights, a sweet green place in which objects can be discerned, odours detected, the temperate climate felt, sounds heard, and fruit consumed. The 'ryveris rennynge' can be both seen and heard, and presumably also felt, if one wishes to dip a toe in or bathe; the flowers can be seen, and their sweet and spicy aromas inhaled; the fruit can be seen, smelled and tasted. Thus each of the senses is fully employed as Paradise, epitome of God's superabundant grace, explodes upon them with divine force. The result of this sensory overload is not confusion, however, but 'mirthe, ioy with-oute ende', as Paradise is transformed into a locus of specifically physical human delight. The indebtedness of this account to the earlier tradition, as we have seen it developed in the Cursor Mundi and especially Walter Daniel, cannot be doubted. The passage is unique within this particular text; nowhere else does the playwright feel it necessary to employ such vivid description in the service of his didactic message. This might suggest that the conventions which shaped fifteenth-century literary descriptions of Paradise were too strong to be ignored; the playwright knew that his audience would expect such language, and did not wish to disappoint them. We might take this further, however. The account of Paradise and its overwhelming sensory pleasures must surely be a source of 
wonder and delight to the audience and, if Augustine is correct, will stimulate the desire for further delight. That desire should, if the didactic purpose of this text is fulfilled, galvanise the will of the listeners to act in order to ensure the salvation of their souls.

A similarly extravagant sensory view of Paradise is encountered in Origo Mundi. This play includes the non-biblical but highly popular episode of Seth, the son of Adam, sent by his dying father to Paradise in search of holy oil. When he reaches Paradise he encounters a cherub who permits him to look inside the gates; Seth then tells him (and the play's audience) what he has seen within:

All the beauty that I saw

The tongue of no man in the world can

Tell it ever.

Of good fruit, and fair flowers, Minstrels and sweet song,

A fountain bright as silver;

And four springs, large indeed, Flowing from it,

That there is a desire to look at them. (766-74)

Again we have flowers, fruit and sweet song, and the 'ryveris rennynge' are also present, this time in the form of 'A fountain, bright as silver; And four springs', which correspond to the biblical river which waters Paradise before dividing into four streams. Here, as in Lucidus and Dubius, the senses are fully represented, but Seth's speech merits further 
consideration. What he sees stimulates his 'desire to look' - that is, the delight he experiences through his senses increases his desire to experience more pleasure. The staging of this scene provokes a similar desire in the audience; Seth pokes his head into a Paradise which is invisible to everyone but himself, and returns to entice us with his description of what he has seen, and to which we cannot gain access. His words thus stimulate our desire to look and see, in a vivid demonstration of Augustine's understanding of the psychology of desire in relation to delight; the more we have, the more we want. Such psychology might place Seth in danger of falling into the trap of sensory delights, being so struck with them that he risks failing to see beyond them, but he is rescued from that risk because his glimpse into Paradise has also revealed something else:

\author{
In it there is a tree, \\ High with many boughs; \\ But they are all bare, without leaves. \\ And around it, bark \\ There was none, from the stem to the head. \\ All its boughs are bare. (775-80)
}

\begin{abstract}
This is, of course, the tree of knowledge, blasted by its role in the Fall. Its presence in Paradise acts as a permanent reminder of man's disobedience, but in Seth's speech it performs the salutary function of drawing his mind back to his father's sin, rather than being carried away by the beauty of the garden. Thus his sensory experiences are interrupted by an object - the withered tree - that requires his interpretation, hence the engagement of his intellect; and it is this which serves to gather up purely sensuous impressions and
\end{abstract}


redirect them towards matters of the intellect and spirit. That this should be so is entirely to be expected, since it is the very function of the tree of knowledge to lead post-lapsarian man back to God; as Sivert Hagan points out, in the earliest versions of the Seth legend, the blasted tree of knowledge is transformed before his eyes into the fertile tree of life, in the boughs of which rests the infant Jesus, exemplifying the necessary connection between the apprehension of $\sin$ and the recognition of Christ as the source of salvation. ${ }^{34}$ In the Origo Mundi version the connection is internalised but is no less explicit: in the taxonomy of Augustine, Seth has progressed from sensory to spiritual delights; in Thomist terms he has ascended from taking pleasure in sense-objects to the pursuit of the higher pleasures of the intellect.

The last of the three texts, the speech of 'Delight' from the commonplace book of Robert Reynes of Acle, at first glance appears to be only tangentially related to the others. Here the speaker, a character named Delight, is not describing Paradise at all; instead he is celebrating the whole created world, in a tone which is not overtly didactic but joyful, playful and even mischievous. Nevertheless, even a cursory comparison reveals linguistic echoes which suggest participation in a shared literary tradition. The speech might best be regarded as a literary cornucopia of created delights, and its capaciousness certainly allows us to think of it in terms of the Creation, especially at the opening; after a brief preamble, Delight begins with a stanza which must surely be heard in the light of the fourth day of Creation in Genesis:

\section{For me semet it is to delyght}

To behelde pe firmament lyght, 
The cours of sterrys to kenne,

The sunne with his bemys bryght, pe mone how he refulsyth pe nyght,

The planetys in her circumferens renne. (13-18)

From the astronomical, Delight's attention moves gradually downwards, from sky and clouds to the leaves of the trees and running waters.

Than of the erthe delyght I take

To see the florent wodys per leves shake,

The ryverys rennyng by perinne dyuers fysshes move. (22-24)

We might almost be back in Walter Daniel's 'second paradise of delight', with rustling branches and fluttering leaves alongside the tumbling waters, and Delight's 'ryverys rennyng' (24) also echo those of Lucidus's description. Just a few lines further on he mentions 'dyuers fowlys [...] swetly syngang' (29-30), and again we think of Lucidus and the 'songe ful swete' that pervades his version of Paradise, as well as the 'sweet song' that Seth reports hearing. These verbal echoes are of course unsurprising, since they reflect the shared literary tradition of describing Paradise already discussed. However, much more suggestive for me is the expression of the pleasure experienced by Delight and reiterated throughout his speech. 'This reioyceth me'; 'delyght I take'; 'I am gretly delyghtand'; 'that plesyth me gretly': again and again we are reminded of delectatio, alongside constant mention of the bodily senses. The major emphasis is on sight, but hearing is also mentioned, and the senses of taste, smell and touch are implied, if not overtly invoked. Like Seth, 
Delight experiences such pleasure from his senses that he cannot help but keep indulging them, to feed his desire for further pleasure. Unlike Seth, however, Delight has no salutary turning away from sensation to intellect; on the contrary, his pleasures incline in the opposite direction, as becomes clear when the list of things in which he takes delight reaches its culmination:

\author{
And pe bewté of women specyaly, \\ With ther whyte pappys poppyd vp prately - \\ pat passeth al other, as me semet in sure. (52-54)
}

\begin{abstract}
Augustine would surely place this last example in his category of carnal delights, since the object of delight - female beauty, in the particular form of pert breasts - is one which he would, one feels, regard as inherently sinful. Indeed, Delight's speech in its entirety can be read as a cautionary example of the dangers of pleasure in Augustinian terms. His opening celebration of the firmament, while strictly worldly, is one which has clear potential to be transformed into a spiritual delight, one which seeks to move towards a closer understanding of God the Creator. Instead, Delight finds himself increasingly distracted by sensory objects, and falls prey to the pleasures they offer. It is perhaps no coincidence that as his speech proceeds the objects of his delight change; from the cosmic they shift to the natural world, thence to cultivated nature in the form of gardens, then to the outdoor pursuits of hunting, and finally, by way of objects of merely human creation, such as houses, fine clothing and music, to the frankly sensual. Thus once again a clear didactic message is built into the text, in a manner which is familiar from other morality plays; one can only
\end{abstract}


speculate on how the play might have ended, but some recognition of the delights of the spirit would surely have been called for.

While it seems clear that these authors are writing within a tradition that Augustine and Aquinas would have recognised, it is less certain how far this reflects direct engagement with the work of these great authority figures, rather than a more general cultural pervasiveness of their ideas; nevertheless, some speculation is possible. The reception of Augustine's writings has been the subject of a comprehensive research project, culminating in the publication of a substantial volume which includes a lengthy chapter by Eric Saak on Augustine in the later Middle Ages; Saak and Karla Pollman have also discussed the issue in two shorter contributions to recently-published companion volumes. ${ }^{35}$ Both Saak and Pollman note the widespread adoption of Augustinian and pseudo-Augustinian material in the period, disseminated at least initially through the religious orders, and particularly (and predictably) the Augustinians themselves. The authors of the three texts under discussion are unknown, but it seems likely, given both the subject-matter and the evidence of other dramatic works from the Middle Ages, that they were clerics; while it is not possible to be more specific, this alone might account for a knowledge of some aspects of Augustine's thought. There is, however, a more substantive connection to be made in the case of Lucidus and Dubius. Augustine is second only to Gregory the Great as a source for the Elucidarium, the Latin text from which Lucidus and Dubius is derived, and the sections in the Latin dealing with Paradise can be related directly back to The Literal Meaning of Genesis and other Augustinian writings. ${ }^{36}$ The influence of Aquinas was probably less widespread in the centuries immediately after his death, at least outside the universities. However, Mishtooni Bose has demonstrated the indebtedness of at least one fifteenth-century writer 
and thinker to the methods, if not the substantive thought, of the Angelic Doctor, indicating that, if Thomist philosophical theology was not ubiquitous, it was at any rate available. ${ }^{37}$ We can therefore speak with a degree of confidence about the general indebtedness of these texts to the theologians, although evidence of more direct influence is limited.

Each of the three dramatic texts I have discussed is, I suggest, performing hard theological work through drama, the most widely accessible of genres. Each text shares in a vocabulary of Paradise which, in the late Middle Ages, was conventional; however, each of them uses this vocabulary to stimulate delight and thereby exploit the psychology of their audiences just as Augustine and Aquinas describe: the experience of pleasure simply increases the desire for further satisfactions, satisfactions which are embedded in the messages of the texts themselves. This knitting together of theology and literature is not, of course, unique to dramatic texts; the late-medieval rise in lay literacy, and the subsequent demand for more sophisticated vernacular theology, generated a large number of literary engagements with difficult theological concerns. ${ }^{38}$ The immersive experience of witnessing drama, however, may be particularly well situated to the exploration of pleasure and delight, which are frequently neglected by other discourses in favour of an emphasis on suffering. ${ }^{39}$ Latemedieval affective devotion, with its attendant focus on the suffering humanity of Christ, may well have stimulated interest in other forms of human feeling, including physical pleasure, and dramatic texts such as those discussed here offer a way of understanding and legitimizing such pleasure in theological terms. The audience of Lucidus and Dubius is left in no doubt that it is only by attending closely to its content that the delights of Paradise can be attained. Origo Mundi makes this point even more explicitly, inviting us to follow Seth's on-stage transition from delight in the sensory pleasures of Paradise to a grasp of the 
spiritual delight which inheres in our recognition of Christ as redeemer of mankind's sin.

And the joys of listening to the personified Delight are an object lesson to the audience, demonstrating how easily our pleasures can be transformed from the spiritual and praiseworthy to the carnal and wicked.

${ }^{1}$ Lucidus and Dubius in Non-Cycle Plays and the Winchester Dialogues, intro. Norman Davis, Leeds Texts and Monographs: Medieval Drama Facsimiles V (Leeds: University of Leeds, 1979), II.202-05. Further references will be by line number from this edition.

${ }^{2}$ Genesis 1-2. All biblical quotations are from the Douay-Rheims edition: http://www.drbo.org.

3 Jean Delumeau, History of Paradise: The Garden of Eden in Myth and Tradition, trans. Matthew O'Connell (Urbana and Chicago: University of Illinois, 2000; first published as Un Histoire du Paradis: Le Jardin des Délices, 1992).

${ }^{4}$ Guy Geltner, 'Eden Regained: William of Ockham and the Franciscan return to Terrestrial Paradise', Franciscan Studies, 59 (2001), 63-89.

${ }^{5}$ Alessandro Scafi, Mapping Paradise: A History of Heaven on Earth (London: British Library, 2006); the terminological discussion is on pp.34-35.

${ }^{6}$ Robert Richard Brandon II, Place, paradise, and perfection: The narrative function of three Middle English versions of paradise, unpublished PhD thesis, University of North Carolina, 2010.

${ }^{7}$ Winston Black, 'William of Auvergne on the Dangers of Paradise: Biblical Exegesis Between Natural Philosophy and Anti-Islamic Polemic', Traditio, 68 (2013), 233-58 (p.248).

${ }^{8}$ Genesis 2:8-15.

${ }^{9}$ Delumeau, Chapter 1.

${ }^{10}$ St Augustine, The Literal Meaning of Genesis, in On Genesis, trans. Edmund Hill OP (New York: New City Press, 2006), Book VIII,1,1. Further references will be to this edition.

${ }^{11}$ St Augustine, On Genesis: A Refutation of the Manichees, in On Genesis, Book II, 9,12.

12 I return to this point in my discussion of the Seth legend below.

${ }^{13}$ See Delumeau, pp.19-21, for Augustine's influence on later commentators.

${ }^{14}$ L'Elucidarium et Les Lucidaires, ed. Yves Lefèvre (Paris: Boccard, 1954), Book 1, qu.69. All future references will be by book and question number from this edition. Translations from the Latin are my own. In referring to the Latin author as Ps.-Honorius I have followed Stephen Morrison's suggestion: The Late Middle English Lucydarye, ed. Stephen Morrison (Turnhout: Brepols, 2013), p. XI, n. 1.

${ }^{15}$ Walter Daniel, The Life of Ailred of Rievaulx, trans. Maurice Powicke (Oxford: Oxford University Press, 1978; first published Thomas Nelson and Sons, 1950), p.12. The manuscript upon which this edition is based is now Manchester, Rylands Library Latin MS 196. I am indebted to Karen Brett for this reference.

${ }^{16}$ As Powicke notes (p.13), Daniel may well have been drawing upon the letter of Bernard of Clairvaux to Aelred prefixed to the Speculum Caritatis, but while Bernard regards the natural world as a possible source of spiritual insight, Daniel seems to regard it as a good in itself. For Bernard's letter, see Aelred of Rievaulx, The Mirror of Charity, trans. Elizabeth O'Connor OCSO (Kalamazoo: Cistercian Publications, 1990), pp.69-72. The passage which appears to have influenced Daniel is on p.70.

${ }^{17}$ Daniel, pp.12-13.

${ }^{18}$ See Qur'an, sura 56 'The Inevitable', 1-40, for a description of the pleasures of the paradise to be enjoyed in the Islamic after-life.

${ }^{19}$ See, for example, Bernard of Clairvaux, Sermons sur le Cantique, intro. and trans. Paul Verdeyen and Raffaele Fassetta (Paris: Editions du Cerf, 1996-2007).

${ }^{20}$ Cursor Mundi, ed. Richard Morris, EETS o.s.57 (London: Oxford University Press, 1874), II.1003-14, $1027-31$. The quotation is from London, British Library MS Cotton Vespasian A III, which is dated to the mid/late fourteenth century; the word 'sautes' in the last line appears as 'foulis' in some other manuscripts. 
${ }^{21}$ Augustine explores delectatio and related concepts across a number of works and only a brief summary is offered here: for a much more comprehensive treatment, to which my own discussion is deeply indebted, see Mark Forbes Moreton Clavier, 'Eloquent Wisdom: The Role of Rhetoric and Delight in the Theology of Saint Augustine of Hippo', unpublished PhD thesis, Durham University (2011).

${ }^{22}$ Clavier, pp.24-25.

${ }^{23}$ St Augustine, Expositions on the Psalms, ed. A. Cleveland Coxe (Grand Rapids: Eerdmans, 1974), Psalm 85:6.

${ }^{24}$ St Augustine, Confessions, trans. R.S. Pine-Coffin (Harmondsworth: Penguin, 1961), Book II, 4. All future references are to this edition.

${ }^{25}$ Clavier, p.25.

${ }^{26}$ Confessions, Book IV, 12.

${ }^{27}$ Clavier, p.215; see Confessions, Book VIII, 3.

${ }^{28}$ St Thomas Aquinas, Summa Theologiae, 1a2ae, 32, 1 and 2.

${ }^{29}$ Summa Theologiae, 1a2ae,32,2 and 3: my emphasis.

${ }^{30}$ Summa Theologiae, 1a2ae,32,8.

${ }^{31}$ Each of these texts is extant in a single manuscript dated to the fifteenth century, although it seems likely that the Origo Mundi was composed slightly earlier: Lucidus and Dubius, Winchester, Winchester College MS 33; Origo Mundi, Oxford, Bodleian Library MS Bodley 791; 'Speech of Delight', Oxford, Bodleian Library MS Tanner 407. Printed texts are as follows: Lucidus and Dubius (see note 1 above); Origo Mundi in The Ancient Cornish Drama, ed. and trans. Edwin Norris, vol. 1 (Oxford: Oxford University Press, 1859); 'Speech of Delight' in Non-Cycle Plays and Fragments, ed. Norman Davis, EETS ss 1 (London: Oxford University Press, 1970). Further references will be by line number from these editions.

${ }^{32}$ For a useful summary see Brian O. Murdoch, 'The cornish medieval drama' in The Cambridge Companion to Medieval English Theatre, ed. Richard Beadle (Cambridge: Cambridge University Press, 1994), pp.211-39.

${ }^{33}$ Iris G. Calderhead, 'Morality Fragments from Norfolk', Modern Philology, 14 (1916), pp.1-9; Richard Rastall, Minstrels Playing: Music in Early Religious Drama (Cambridge: Brewer, 2001), pp.484-85.

${ }^{34}$ See the discussion in Sivert N. Hagan, 'The Origin and Meaning of the Name Yggdrasill', Modern Philology, 1.1 (1903), 57-69 (pp. 62-64).

${ }^{35}$ Eric Saak. 'The Augustinian Renaissance: Textual Scholarship and Religious Identity in the Later Middle Ages (1200-1500), in The Oxford Guide to the Historical Reception of Augustine, ed. Willemien Otten (Oxford: Oxford University Press, 2013), pp.blah; see also Saak, 'Augustine in the Western Middle Ages to the Reformation', in A Companion to Augustine, ed. Mark Vessey (Oxford: Wiley-Blackwell, 2012), pp. 465-77, and Karla Pollman, 'Augustine's legacy: success or failure?' in The Cambridge Companion to Augustine, ed. David Vincent Meconi and Eleonore Stump (Cambridge: Cambridge University Press, 2014), pp. 331-48.

${ }^{36}$ L'Elucidarium et Les Lucidaires, Book 1, qus 65-69; and see Lefèvre's notes on p. 117.

${ }^{37}$ Mishtooni Bose, 'Two Phases of Scholastic Self-Consciousness: Reflections on Method in Aquinas and Peock', in Aquinas as Authority, ed. Paul van Geest, Harm Goris and Carlo Leget (Leuven: Peeters, 2002), pp. 87-108.

${ }^{38}$ See, for example, the religious exempla included in Geoffrey Chaucer's The Canterbury Tales and John Gower's Confessio Amantis; William Langland's Piers Plowman; and John Capgrave's Life of St Katherine of Alexandria.

${ }^{39}$ I am thinking here particularly of texts in the Ps.-Bonaventuran tradition, such as Nicholas Love's Mirror of the Blessed Life of Jesus Christ, and other related texts. 